\title{
PARTISIPASI MASYARAKAT DALAM PROGRAM BANTUAN STIMULAN PERUMAHAN SWADAYA (BSPS) DI DESA KOTO BARU KECAMATAN KOTO BARU (2020)
}

\author{
PEBI JULIANTO
}

\author{
IAIN KERINCI
}

email:

pebijulianto@gmail.com

\begin{abstract}
Community Participation in a Self-Help Housing Stimulation Program (BSPS) in Koto Baru Village in Koto Baru (2020) with the problem formulation How is Community Participation in a Self-Help Housing Stimulant Assistance Program (BSPS) in Koto Baru Village in Koto Baru (2020) ?Research Objectives To determine Community Participation in a Self-Help Housing Stimulant Assistance Program (BSPS) in Koto Baru Village in Koto Baru (2020). This study uses a qualitative approach where data is obtaneid through field interviews of 9 informants who refer to the research indicators namely, (1) Stages of participation (2)Type of participation (3)Level of participation (4) Faktors that affect participation. The data obtained in the field were analyzed based on researchers' interpretation which then triangulated the data and displayed excerpts of answers from research informants. The result of this study can be concluded that the Koto Baru Village has the right to be made a priority in the BSPS program, the community Participation is considered lacking in the implementation of the BSPS Program, the contributing factors are the lack of self-help in the form of money form government and the community is not involved in decision making, for that the authors suggest that the government directs, guides and controls the implementation of the BSPS program in the future so that it can run well.
\end{abstract}

Keywords: Participation, Society, Participation factors

\begin{abstract}
ABSTRAK
Partisipasi Masyarakat dalam Program Bantuan Perumahan Swadaya (BSPS) di Desa Koto Baru Kecamatan Koto Baru (2020) dengan rumusan masalah Bagaimana Partisipasi Masyarakat dalam Program Bantuan Stimulan Perumahan Swadaya (BSPS) di Desa Koto Baru Kecamatan Koto Baru (2020)? Tujuan penelitian Untuk mengetahui Partisipasi Masyarakat dalam Program Bantuan Stimulan Perumahan Swadaya (BSPS) di Desa Koto Baru Kecamatan Koto Baru (2020). Penelitian ini menggunakan pendekatan kualitatif dimana data diperoleh melalui wawancara dilapangan terhadap 9 orang informan yang mengacu kepada indikator penelitian yaitu, (1) Tahapan partisipasi (2) Jenis partisipasi (3) Tingkat partisipasi (4) Faktor yng mempengaruhi partisipasi. Data yang diperoleh dilapangan dianalisis berdasarkan interpretasi Penulis yang kemudian dilakukan triangulasi data dan menampilkan kutipan-kutipan jawaban dari informan penelitian. Hasil penelitian ini dapat disimpulkan bahwa desa Koto Baru berhak dijadikan prioritas dalam program BSPS, partisipasi masyarakat dinilai kurang dalam pelaksanaan program BSPS ini, faktor penyebabnya adalah kurangnya swadaya berupa uang dari pemerintah dan masyarakat tidak dilibatkan dalam pengambilan keputusan, untuk itu Penulis menyarankan agar pemerintah daerah untuk lebih mengarahkan, membimbing dan mengontrol dalam pelaksanaan Program BSPS untuk kedepannya agar dapat berjalan dengan baik.
\end{abstract}

Kata Kunci: Partisipasi, Masyarakat, Faktor-faktor partisipasi 


\section{PENDAHULUAN}

Pembangunan suatu negara pada dasarnya bertujuan untuk meningkatkan kesejahteraan masyarakat yang mempunyai kaitan erat dengan nilai, strategi, serta indikator yang sekaligus menjadi dominan setiap negara berkembang. Demikian halnya dengan negara Indonesia, pelaksanaan kegiatan pembangunan di Indonesia merupakan salah satu yang menjadi hak dasar fundamental bagi setiap orang berhak hidup sejahtera lahir dan batin, bertempat tinggal dan mendapatkan lingkungan hidup yang baik dan sehat serta berhak memperoleh pelayanan kesehatan yang tertera pada Pasal $28 \mathrm{H}$ ayat 1 Undang-Undang Dasar 1945.

Perumahan dan pemukiman kumuh yang cenderung meluas ini perlu segera ditangani, sehingga dihadapkan terwujud suatu lingkungan perumahan dan pemukiman yang layak huni dalam suatu lingkungan yang sehat, aman, serasi dan teratur. Kondisi ini telah menjadi agenda penting pemerintah dengan mempertimbangkan bahwa perumahan telah mejadi Hak Asasi sebagaimana dicantumkan dalam Pasal 40 Undang-Undang Nomor 39 Tahun 1999 tentang Hak Asasi Manusia yang menyatakan setiap orang berhak untuk bertempat tinggal serta berkehidupan yang layak.

Pemerintah Republik Indonesia melalui Kementerian Pekerjaan Umum dan Perumahan Rakyat membuat suatu program yang berorientasi pada pembangunan salah satunya adalah program Bantuan Stimulan Perumahan Swadaya (BSPS) bagi Masyarakat Berpenghasilan Rendah (MBR). Bantuan Stimulan Perumahan Swadaya (BSPS) diatur dalam Peraturan Kementerian Pekerjaan Umum dan Perumahan Rakyat (PUPR) Nomor 07/PRT/M/2018 tentang Bantuan Stimulan Perumahan Swadaya (BSPS) adalah penyelenggaraan yang dilaksanakan melalui kegiatan peningkatan kualitas rumah swadaya serta intensif pembangunan baru rumah swadaya. Berpedoman pada materi Undang-Undang Nomor 1 Tahun 2011 tentang perumahan dan kawasan permukiman pada dasarnya keterlibatan masyarakat tidak hanya pada upaya pemenuhan rumah secara fisik tetapi juga meliputi keseluruhan proses mulai dari perencanaan sampai pengawasan.

Pelaksanaan pembangunan ini berjalan dari bulan Februari hingga Agustus 2020, pelaksanaan program terlampaui dari target pelaksanaan 3 bulan menjadi 7 bulan. Terlambat 4 bulan dengan waktu yang telah ditetapkan, namun pelaksanaan program BSPS di desa Koto Baru dapat terlaksana walaupun pelaksanaan program berjalan lebih lama dari waktu yang telah ditetapkan sebelumnya yang disebabkan kurangnya swadaya masyarakat terhadap program BSPS ini. Penulis menilai masyarakat desa Koto Baru aktif dalam partisipasi program bantuan BSPS ini yang disebabkan oleh keterbatasan sumber daya yang dimiliki oleh sebagian masyarakat.

\section{Tinjauan Pustaka}

\section{Pengertian Partisipasi Masyarakat}

Pengertian partisipasi secara umum adalah keikutsertaan seseorang atau sekelompok anggota masyarakat dalam suatu kegiatan. Menurut Pidarta dalam Dwiningrum (2011:50) partisipasi adalah pelibatan seseorang atau beberapa orang dalam suatu kegiatan. Keterlibatan mental dan emosi serta fisik dalam menggunakan segala kemampuan yang dimilikinya (berinisiatif) dalam segala kegiatan yang dilaksanakan serta mendukung pencapaian tujuan dan tanggung jawab atas segala keterlibatan.

Partisipasi menurut Huneryear dan Hecman dalam Dwiningrum (2011:51) adalah sebagai keterlibatan mental dan emosional individu dalam situasi kelompok yang mendorongnya memberi sumbangan terhadap tujuan kelompok serta membagi tanggung 
jawab bersama mereka. Selain itu, Bornby dalam Mardikanto dan Soebiato (2015:81) mengartikan partisipasi sebagai tindakan untuk "mengambil bagian" yaitu kegiatan atau pernyataan untuk mengambil bagian dari kegiatan dengan maksud memperoleh manfaat.

\section{METODE PENELITIAN}

\section{Pendekatan Penelitian}

Pendekatan yang digunakan dalam penelitian ini adalah metode kualitatif, yang artinya metode (jalan) yang di mana penelitian yang bersifat sistematis yang digunakan untuk mengkaji atau meneliti suatu objek pada latar alamiah tanpa ada manipulasi didalamnya dan tanpa ada pengujian hipotesis.

\section{Informan Penelitian}

Menurut Sugiyono (2013:91) teknik penentuan informan adalah teknik pengambilan sampel untuk menentukan sampel yang akan digunakan dalam penelitian. Dalam penelitian kualitatif proses sampling adalah bagaimana menentukan informasi kunci atau situasi sosial tertentu yang serta informasi sesuai fokus penelitian, Burhan Bugin (2003:53)

Untuk pemilihan informan dalam penelitian ini memakai teknik purposive sampling yang merupakan teknik untuk menentukan sampel penelitian dengan beberapa pertimbangan tertentu yang bertujuan agar data yang diperoleh nantinya bisa lebih refrensetatif.

\section{Data Yang Akan Diambil}

Menurut Lofland dalam Moleong (2012:157) sumber data utama dalam penelitian kualitatif adalah kata-kata dan tindakan, selebihnya adalah data tambahan seperti dokumen dan lain-lain. Sumber data di dalam penelitian merupakan faktor yang sangat penting, karena sumber data akan menyangkut kualitas dari hasil penelitian, jenis data yang digunakan adalah data primer dan data sekunder.

\section{Teknik Pengumpulan Data}

\section{Observasi}

Sebagai pengamatan dan pencatatan secara sistematik dari fenomena-fenomena yang diselidiki.

2. Wawancara

Wawancara dilakukan untuk mendapatkan informasi lebih dalam dan untuk menunjang dalam menginterprestasi data kualitatif.

3. Dokumentasi

Dokumentasi adalah suatu cara yang digunakan untuk memperoleh data dan informasi dalam bentuk buku, dokumen, arsip, tulisan angka dan gambar yang berupa laporan serta keterangan yang dapat mendukung penelitian, Sugiyono (2013:222).

\section{Interpretasi Data}

1. Pengumpulan Data / Reduksi

Dalam penelitian ini peneliti menggunakan teknik pengumpulan data secara wawancara, wawancara yang dilakukan terhadap sumber informasi yang dinilai dapat memberikan informasi yang akurat terhadap studi kasus dalam penelitian ini.

2. Penyajian Data

Miles dan Huberman dalam Sugiyono (2013:339) menyatakan bahwa yang paling sering digunakan untuk menyajikan data dalam penelitian kualitatif adalah teks yang bersifat naratif.

3. Metode Triangulasi 
Teknik pemeriksaan keabsahan data yang memanfaatkan sesuatu yang lain diluar data itu untuk keperluan pengecekan atau pembanding.

4. Penarikan Kesimpulan

Penarikan kesimpulan merupakan kegiatan akhir dalam pembuatan laporan hasil penelitian yang telah dilakukan.

\section{HASIL DAN PEMBAHASAN}

\section{Tahapan Partisipasi Masyarakat}

\section{Partisipasi Masyarakat Dalam Pengambilan Keputusan}

Berdasarkan hasil wawancara dengan beberapa informan yaitu masyarakat penerima program BSPS tentang partisipasi masyarakat dalam pengambilan keputusan sebagai berikut:

Wawancara dengan Ibu Nurnisyati pukul 11.00 Wib Hari Kamis 10 September 2020 mengatakan,

"Dalam pengambilan keputusan kami di ikut sertakan termasuk dalam penentuan toko bangunan untuk mengambil bahan yang kami butuhkan".

Wawancara dengan Ibu Sansuarni pukul 13.30 Wib Hari Kamis 10 September 2020 mengatakan,

"Selama pelaksanaan BSPS di desa kami, didalam pengambilan keputusan kami sering dilibatkan didalamnya kami mengikuti apa keputusan yang telah dibuat dengan kesepakatan bersama oleh kami penerima terlebih bantuan".

Wawancara dengan Ibu Hernita pukul 15.00 Wib Hari Kamis 10 September 2020 mengatakan,

"Apapun saran dalam pengambilan keputusan yang kami berikan selalu didukung oleh fasilitator".

Wawancara dengan Ibu Maidartisna pukul 09.30 Wib Hari Sabtu 12 September 2020 mengatakan,

"Dalam pengambilan keputusan saya rasa apapun yang telah kami putuskan sesuai dengan apa tujuan bersama".

Pendapat dari informan yaitu masyarakat penerima program BSPS disetujui oleh informan kunci Bapak Petriadi pukul 08.40 Wib Hari Kamis 10 September 2020 menjelaskan,

"Dalam pengambilan keputusan masyarakat penerima bantuan selalu dilibatkan didalam semua pengambilan keputusan baik itu untuk kepentingan bersama maupun untuk perorangan, masyarakat penerima pun banyak memberi saran kepada kami untuk kesuksesan program ini, dan saya rasa partisipasi dalam pengambilan keputusan mereka sangat baik”.

Dari penjelasan diatas penulis mengimlikasikan bahwa tidak terjadi kekeliruan dalam melibatkan masyarakat dalam pengambilan keputusan dan itu bisa berdampak pada ke lancaran program ini, namun dari Kepala desa menyetujui pendapat dari masyarakat penerima bantuan dengan mengatakan selalu mengikut sertakan masyarakat dalam pengambilan keputusan. 


\section{Partisipasi Masyarakat Dalam Pelaksanaan}

Partisipasi dalam pelaksanaan dapat diartikan sebagai suatu tindakan atau sebuah rencana yang disusun secara matang dan terperinci, secara sederhana pelaksanaan bisa diartikan penerapan.

Ketika wawancara dengan informan yaitu masyarakat penerima program BSPS tentang bagaimana partisipasi masyarakat dalam pelaksanaan, informan menjelaskan,

Wawancara dengan Ibu Nurnis yati pukul 11.05 Wib Hari Kamis 10 September 2020

"Dalam pelaksanaan saya merasa masyarakat yang tidak menerima bantuan ini tidak mengikuti dengan baik, banyak yang tidak ikut membantu".

Wawancara dengan Ibu Sansuarni pukul 13.35 Wib Hari Kamis 10 September 2020

"Saya mengikuti dalam pelaksanaannya dan masyarakat yang tidak menerima bantuan tidak begitu memperhatikan pekerjaan yang dilakukan dalam perbaikan rumah kami”.

Wawancara dengan Ibu Hernita pada 15.05 Wib Hari Kamis 10 September 2020

"Tidak ada masyarakat yang ikut membantu kami dalam melaksanakan bantuan ini, cuma tukang yang diupah yang bekerja perbaikan rumah sampai selesai”.

Wawancara dengan Ibu Maidartisna pukul 09.35 Wib Hari Sabtu 12 September 2020

"Dalam melaksanakan bantuan ini masyarakat yang tidak menerima bantuan terkesan membiarkan kami melakukannya sendiri beserta tukang dalam perbaikan rumah".

Wawancara dengan Ibu Pera Satria pukul 11.00 Wib Hari Sabtu 12 September 2020

"Saya mengikuti dalam pelaksanaannya dan masyarakat yang tidak menerima bantuan tidak begitu memperhatikan pekerjaan yang dilakukan dalam perbaikan rumah kami”.

Wawancara dengan Ibu Marna pukul 09.10 Wib Hari Senin 14 September 2020

"Saya berterima kasih karena masyarakat dan pemerintah daerah telah ikut membantu dalam perbaikan rumah saya, sehingga rumah saya yang tidak layak huni menjadi rumah layak huni”.

Wawancara dengan Ibu Trismil Yanti pukul 11.12 Wib Hari Senin 14 September 2020

"Saya cukup antusias dalam bantuan ini dengan bahan bangunan yang baik".

Wawancara dengan Ibu Delfi Afrina pukul 10.31 Hari Selasa 15 September 2020 "Dalam pelaksanaan bantuan yang diberikan kepada kami terutama saya sendiri sangat bersemangat agar rumah saya bisa diperbaiki dan bisa dihuni dengan layak". 
Penjelasan dari informan diatas diperkuat lagi oleh informan kunci yaitu Bapak Petriadi pukul 08.45 Wib Hari Kamis 10 September 2020 menjelaskan,

"Tanggapan dan respon masyarakat dalam berpartisipasi sangat baik dalam pelaksanaan mereka melakukannya secara bergotong royong dan semua masyarakat ikut membantu baik itu penerima BSPS maupun yang tidak menerima BSPS di desa Koto Baru".

Berdasarkan penjelasan dari informan yaitu masyarakat penerima program BSPS dan pendapat dari informan kunci maka penulis dapat menyimpulkan bahwa, masyarakat baik dalam berpartisipasi terutama masyarakat yang menerima bantuan.

\section{Partisipasi Masyarakat Dalam Pemanfaatan Hasil dan Evaluasi}

Partisipasi masyarakat dalam pemanfaatan hasil penulis menilai semua memanfaatkan program bantuan BSPS dengan baik tapi penulis menemukan banyak keluhan, saran maupun evaluasi oeh masyarakat penerima BSPS seperti yang disampaikan oleh informan penerima program yaitu Ibu Pera Satria dan Ibu Marna, sebagai berikut

Wawancara dengan Ibu Pera Satria pukul 11.05 Wib Hari Sabtu 12 September 2020

"Untuk kedepannya saya berharap kepada pemerintah untuk lebih memerhatikan dalam memilih calon penerima, karena masih ada masyarakat yang berpenghasilan rendah tidak mendapat bantuan ini”.

Wawancara dengan Ibu Marna pukul 09.15 Wib Hari Senin 14 September 2020 "Hal yang harus dievaluasi oleh Pemerintahan Daerah yaitu bagi kami penerima bantuan yang usianya diatas 50 tahun terkadang sebagian dari kami penerima umur diatas 50 tahun mendapatkan subsidi dari pemerintah untuk membayar upah tukang cuma beberapa yang mendapatkan".

Wawancara dengan Ibu Delfi Afrina pukul 10.33 Wib Hari Selasa 15 September 2020

"Kami mengharapkan untuk kedepannya masyarakat ikut berpartisipasi dalam bantuan ini sehingga program ini dapat selesai dalam waktu yang telah ditentukan".

Wawancara dengan Ibu Maidartisna pukul 09.33 Wib Hari Sabtu 12 September 2020

"Saya berharap kedepannya dalamprogram ini bisa selesai sesuai dengan target".

Ketika wawancara dengan informan kunci Bapak Petriadi pukul 08.50 Wib Hari Kamis 10 September 2020 tentang Bagaimana partisipasi pemanfaatan hasil dan evaluasi, beliau menjelaskan

"Cara masyarakat berpartisipasi didalam pemanfaatan hasil tentunya dengan cara menjaga maupun merawat rumah yang telah diperbaiki sehingga dapat mengurangi rumah tidak layak huni yang ada di desa Koto Baru”.

Berdasarkan dari penjelasan informan yaitu masyarakat penerima program BSPS dan pendapat informan kunci, penulis dapat menyimpulkan bahwa partisipasi masyarakat dalam pemanfaatan hasil dan evaluasi cukup baik yaitu dengan cara menempati dan merawat rumah 
yang telah diperbaiki dengan baik agar dapat mengurangi rumah tidak layak huni di desa Koto Baru.

\section{Jenis Partisipasi Masyarakat}

Ketika wawancara dengan beberapa informan yaitu masyarakat penerima bantuan tentang Bagaimana keterlibatan masyarakat terhadap perbaikan rumah dalam program Bantuan Stimulan Perumahan Swadaya mengatakan,

Wawancara dengan Ibu Trismil Yanti pukul 11.20 Wib Hari Senin 14 September 2020

"Dalam bantuan ini kami sepenuhnya dilibatkan terutama dalam proses perbaikan rumah".

Wawancara dengan Ibu Delfi Afrina pukul 10.35 Wib Hari Selasa 15 September 2020

"Kami dilibatkan dalam bantuan, kami menerima apa yang telah ditentukan oleh keputusan bersama".

Wawancara dengan Ibu Hernita pukul 15.02 Wib Hari Kamis 10 September 2020

"Masyarakat yang tidak menerima tidak dilibatkan sepenuhnya dalam bantuan ini karena pemerintah hanya mengutamakan penerima BSPS yang ikut terlibat dalam penyelenggaraan sosialisasi maupun pelaksanaan”.

Wawancara dengan Ibu Sansuarni pukul 13.32 Wib Hari Kamis 10 September 2020

"Saya melihat masyarakat yang tidak menerima bantuan ini tidak dilibatkan dalam pelaksanaan, hanya kami penerima yang dilibatkan dalam bantuan ini”.

Wawancara dengan Ibu Nurnis yati pukul 11.03 Wib Hari Kamis 10 September 2020

"Menurut saya semua masyarakat disini ikut terlibat terutama penerima bantuan ini, baik itu dalam menentukan toko bangunan dan perbaikan rumah".

Ketika wawancara dengan informan kunci yaitu Kepala desa Koto Baru Bapak Petriadi pukul 09.00 Wib Hari Kamis 10 September 2020 tentang Bagaimana keterlibatan masyarakat terhadap perbaikan rumah dalam program Bantuan Stimulan Perumahan Swadaya, beliau menjelaskan

"Dalam program ini kami dari pemerintahan desa selalu melibatkan masyarakat baik itu perencanaan maupun pelaksanaan bantuan ini dan masyarakat pun sangat antusias dalam ikut melibatkan diri”.

Berdasarkan hasil wawancara diatas ada ketidak sesuaian antara informan kunci dengan informan penerima BSPS tentang keterlibatan masyarakat dalam program BSPS. Dimana informan kunci mengatakan bahwa telah melibatkan masyarakat, sedangkan menurut informan penerima bantuan mereka menerima ketentuan dari keputusan bersama. 


\section{Tingkatan Partisipasi Masyarakat}

Berdasarkan hasil wawancara dengan beberapa informan penerima BSPS tentang Bagaimana partisipasi masyarakat mengenai sosialisasi program Bantuan Stimulan Perumahan Swadaya, informan menjelaskan

Wawancara dengan Ibu Nurnis yati pukul 11.10 Wib Hari Kamis 10 September "Menurut saya sosialisasi cukup membantu dalam mendapatkan bantuan ini dan saya sangat berterima kasih kepada pemerintah baik dalam memberikan informasi serta kepedulian terhadap masyarakat yang rumahnya tidak layak huni menjadi rumah layak huni”.

Wawancara dengan Ibu Sansuarni pukul 13.40 Wib Hari Kamis 10 September "Saya merasa sosialisasi dalam pengurusan administrasi dalam bantuan ini ada sedikit kendala, sehingga dalam mendapatkan rumah layak huni butuh proses yang cukup lama".

Wawancara dengan Ibu Hernita pukul 15.10 Wib Hari Kamis 10 September "Sosialisasi yang dilaksanakan ini tidak tertutup untuk masyarakat yang berpenghasilan diatas rata-rata, menurut saya pemerintah sudah jelas dalam memberikan informasi tentang pengurusan administrasinya".

Wawancara dengan Ibu Maidartisna pukul 09.40 Wib Hari Sabtu 12 September 2020

"Menurut saya keterbukaan mengenai bantuan ini sudah baik, walaupun penerimanya telah ditentukan oleh pemerintah desa dan pemerintah kurang begitu jelas dan sulit dipahami dalam memberikan informasi tentang bantuan ini”.

Wawancara dengan Ibu Marna pukul 09.20 Wib Hari Senin 14 September 2020

"Dalam sosialisasi kemarin saya melihat hanya masyarakat yang layak mendapatkan bantuan ini yang diundang dan tidak terbuka untuk seluruh masyarakat Koto Baru, sehingga berkurangnya pasrtisipasi masyarakat dalam bantuan ini”".

Wawancara dengan informan kunci yaitu Kepala desa Koto Baru tentang Bagaimana partisipasi masyarakat mengenai sosialisasi program Bantuan Stimulan Perumahan Swadaya, Bapak Petriadi pukul 09.05 Wib Hari Kamis 10 September 2020, beliau menjelaskan

"Dalam sosialisasi Program Bantuan Stimulan Perumahan Swadaya memang hanya Masyarakat Berpenghasilan Rendah yang diundang untuk mengikutinya dan pemerintah pusat memberi bantuan ini untuk daerah Koto Baru sekitar 36 Kepala Keluarga, tanggapan dan respon masyarakat yang tidak menerima bantuan ini cukup baik dan mereka bisa memahami penerima bantuan ini memang masyarakat yang rumahnya tidak layak huni karena kondisi dari rumah tersebut memang pantas untuk diperbaiki dan dalam sosialisasi ini berjalan cukup lancar dan masyarakat ikut berpartisipasi sesuai prosedur yang telah ditentukan sehingga program ini dapat berjalan dengan baik".

Berdasarkan hasil wawancara tentang Bagaimana partisipasi masyarakat mengenai sosialisasi program Bantuan Stimulan Perumahan Swadaya dinilai kurang baik karena 
menurut informan penerima BSPS mengatakan sosialisasi ini diselenggarakan secara tertutup untuk masyarakat yang tidak menerima bantuan ini sehingga menyebabkan berkurangnya partisipasi masyarakat dalam program Bantuan Stimulan Perumahan Swadaya.

\section{Faktor Yang Mempengaruhi Partisipasi \\ Faktor Pendorong Partisipasi}

Penjelasan dari beberapa informan yaitu masyarakat penerima program BSPS tentang faktor pendorong partisipasi menjelaskan

Wawancara dengan Ibu Trismil Yanti pukul 11.25 Wib Hari Senin 14 September 2020

"Yang menjadi pendorong kami tentunya yaitu membuat rumah kami lebih baik dan saya merasa sangat terbantu karena adanya bantuan ini untuk memperbaiki rumah saya".

Wawancara dengan dengan Ibu Delfi Afrina pukul 10.38 Wib Hari Selasa 15 September 2020

"Pendorong partisipasi kami adalah dengan adanya bantuan BSPS ini lebih meringankan kami dalam perbaikan rumah yang kami huni”.

Penjelasan dari informan diatas dikuatkan juga dari penjelasan informan kunci Bapak Petriadi pukul 09.10 Wib Hari Kamis 10 September 2020, menjelaskan

"Pendorong partisipasi masyarakat dalam program BSPS tentunya dengan adanya bantuan ini masyarakat bersemangat mensukseskan program ini untuk memperbaiki rumah mereka yang tidak layak huni".

Dari penjelasan diatas dapat disimpulkan bahwa yang menjadi pendorong masyarakat dalam pelaksanaan program BSPS tentunya adalah dengan adanya program ini bisa meringankan beban masyarakat.

\section{Faktor Penghambat Partisipasi}

Ketika Penulis mewawancarai informan yaitu masyarakat penerima program BSPS tentang faktor-faktor penghambat dalam partisipasi masyarakat, semua informan yang penulis tanyakan faktor penghambatnya yaitu kurangnya swadaya berupa uang. Berikut hasil wawancara penulis kepada beberapa informan

Wawancara dengan Ibu Pera Satria pukul 11.10 Wib Hari Sabtu tanggal 12 September 2020, mengatakan

"Penghambat saya dalam bantuan ini salah satunya adalah kekurangan swadaya yang menyebabkan rumah yang diperbaiki tidak sesuai dengan apa yang saya harapkan".

Wawancara dengan Ibu Marna pukul 09.20 Wib Hari Senin 14 September 2020

"Penghambatnya menurut saya adalah kurangnya partisipasi masyarakat dalam pelaksanaan sehingga proses pelaksanaan cukup lama dan kurangnya swadaya yang diberikan pemerintah".

Dari wawancara penulis diatas juga diperkuat oleh informan kunci Petriadi pukul 09.20 Wib Hari Kamis 10 September 2020, beliau menjelaskan

"Faktor yang menjadi penghambat partisipasi masyarakat yaitu pertama adalah kurangnya swadaya uang dari masyarakat karena dalam program ini masyarakat 
juga diminta swadaya berupa uang gunanya untuk menambah apabila terjadi kekurangan biaya selama pekerjaan berlangsung".

Dari penjelasan diatas dapat disimpulkan bahwa faktor penghambat partisipasi masyarakat adalah kurangnya swadaya dari sebagian masyarakat penerima BSPS karena mengingat hampir seluruh masyarakat penerima bantuan bekerja sebagai buruh tani.

\section{SIMPULAN}

Berdasarkan hasil penelitian melalui wawancara dengan informan tentang Partisipasi Masyarakat Dalam Program Bantuan Stimulan Perumahan Swadaya (BSPS) Desa Koto Baru Tahun 2020, dapat disimpulkan yaitu:

1. Partisipasi pengambilan keputusan

Pengambilan keputusan dinilai baik karena pengambilan keputusan dilakukan secara bersama penerima bantuan dengan pemerintah desa dan Fasilitator.

2. Partisipasi dalam pelaksanaan

Masyarakat yang tidak menerima BSPS dinilai kurang baik dalam berpartisipasi, sehingga adanya ketidak lancaran dalam pelaksanaan bantuan ini di desa Koto Baru.

3. Partisipasi dalam pemanfaatan hasil dan evaluasi

Partisipasi masyarakat dalam pemanfaatan hasil cukup baik yaitu dengan cara menempati dan menjaga rumah yang telah diperbaiki dengan baik agar dapat mengurangi rumah tidak layak huni di desa Koto Baru.

4. Dalam jenis partisipasi tentang keterlibatan masyarakat dalam program BSPS adanya kesesuaian antara informan kunci dengan informan penerima BSPS. Dimana informan kunci mengatakan bahwa telah melibatkan masyarakat, sedangkan menurut informan penerima bantuan mereka juga menerima ketentuan bersama.

5. Dalam tingkat partisipasi tentang Bagaimana partisipasi masyarakat mengenai sosialisasi program Bantuan Stimulan Perumahan Swadaya dinilai baik karena menurut informan penerima BSPS mengatakan sosialisasi ini diselenggarakan secara terbuka untuk masyarakat yang menerima bantuan ini sehingga menyebabkan meningkatnya partisipasi masyarakat dalam program Bantuan Stimulan Perumahan Swadaya.

6. Faktor Pendorong

Pendorong masyarakat dalam pelaksanaan program BSPS tentunya adalah dengan adanya program ini bisa meringankan beban masyarakat dan tercapainya rumah yang layak untuk di huni.

7. Faktor Penghambat

Kurangnya swadaya dari sebagian masyarakat penerima BSPS karena mengingat hampir seluruh masyarakat penerima bantuan bekerja sebagai buruh tani.

8. Rekomendasi

Penulis merekomendasikan program ini untuk terus dilaksanakan karena sangat membantu masyarakat dan system penyaluran dengan mekanisme yang sudah begitu baik.

\section{UCAPAN TERIMAKASIH}


Diucapkan terima kasih kepada semua pihak yang telah berkontribusi dalam penulisan jurnal ini, sehingga jurnal ini dapat diselesaikan dengan baik. Dan juga terima kasih kepada penglola jurnal Qawwam, sehingga bisa dipublikasan di OJS Qawwam.

\section{DAFTAR PUSTAKA}

Budi Winarno, 2012. Kebijakan Publik(Teori, Proses dan Studi Kasus). Yogyakarta: CAPS

Burhan Bugin, 2003. Ringkasan dan Ulasan buku Analisis Data Penelitian Kualitatif. Hengki Wijaya.

Pebi Julianto. 2014. Evaluasi Pelaksanaan Program Satu milyar Satu kecamatan (Samisake) di kecamatan Depati Tujuh Kabupaten Kerinci Provinsi jambi tahun 2014. OSF Preprints. Jakarta.

Huraerah Abu, 2008.pengorganisasian dan pengembangan masyarakat:Model dan strategi pembangunan berbasis kerakyatan. Bandung:Humaniora.

Rusidy Syahra, 2003. Modal Sosial: Konsep dan aplikasi. Jurnal Masyarakat dan BudayaVol.5 No.01.

Siti Irene Astuti Dwiningrum, 2011. Desentralisasi dan Partisipasi Masyarakat dalam Pendidikan. Yogyakarta:Pustaka Belajar.

Pebi Julianto. 2020. Pengaruh Disiplin Kerja Terhadap Prestasi Kerja Pegawai pada Puskesmas di kecamatan Depati VII Kabupaten Kerinci. E Jurnal Administrasi Nusantara. Sungai Penuh.

Sugiyono, 2013. Metode Penelitian Kualitatif. Bandung: Alfabeta.

Sulistio Eko Budi, 2009. Kebijakan Publik (public policy) Kerangka Dasar Studi Kebijakan Publik. Lampung.

Pebi Julianto. 2018. Pengaruh Sistem Kearsipan Terhadap Efisiensi Kerja Pada koantor Camat Air Hangat Kabupaten Kerinci. E Jurnal Administrasi Nusantara. Sungai Penuh.

Syintia Bela Tama, 2017. Partisipasi Masyarakat dalam Program Bantuan Stimulan Perumahan Swadaya. Universitas Lampung.

Pebi Julianto. 2018. Pengaruh Pengetahuan dan Keterampilan Terhadap Prestasi Kerja Pegawai Pada Mtsn Model Sungai Penuh. E Jurnal Administrasi Nusantara. Sungai Penuh.

Paul H. Dauglas, Wahyudi Kumorotomo 1992. Ketentuan Transparansi dalam Pelayanan Publik.

Pebi Julianto. 2020. Implementasi Program Bantuan Pangan non Tunai (BPNT) di Kecamatan Sitinjau Laut Kabupaten Kerinci. E Jurnal Qawwam. Kerinci. 
Totok Mardikanto dan Poerwoko Soebiato, 2018. Analisis Pasrtisipasi Masyarakat dalam Program Padat Karya. Jurnal Devi Tri Meilinawati, Vol.02 No.02.

Peraturan Kementerian Pekerjaan Umum dan Perumahan Rakyat Republik Indonesia Nomor: 07/SE/Dr/2018.

Undang-Undang Dasar 1945, Pasal 28H Ayat (1) disebutkan bahwa:

Setiap orang berhak hidup sejahtera lahir dan batin, bertempat tinggal, dan mendapatkan lingkungan hidup yang baik dan sehat, berhak memperoleh pelayanan kesehatan.

Undang-Undang Nomor 39 Tahun 1999 Pasal 40 tentang Hak Asasi Manusia, yang menyatakan setiap orang berhak bertempat tinggal serta berkehidupan yang layak.

Undang-Undang Nomor 1 Tahun 2011 Tentang pedoman pelaksanaan Bantuan Stimulan Perumahan Swadaya (BSPS). 